\begin{tabular}{|c|c|c|c|c|c|}
\hline $\begin{array}{l}\text { Second } \\
\text { Set. }\end{array}$ & $\begin{array}{l}1856 \\
1857 \\
1859 \\
1863 \\
1869 \\
1876 \\
1878\end{array}$ & $\begin{array}{r}3 \cdot T \\
7 \cdot 8 \\
9 \cdot 2 \\
9^{\circ} \cdot 5 \\
8 \cdot 2 \\
4 \cdot 8 \\
5^{\circ} \cdot 9\end{array}$ & $\begin{array}{l}1856 \\
1857 \\
1859 \\
1864 \\
1869 \\
1876 \\
1878\end{array}$ & $\begin{array}{r}4.7 \\
9.1 \\
11.0 \\
5.9 \\
9.2 \\
7.8 \\
10.5\end{array}$ & $\begin{array}{l}+1 \cdot 6 \\
+1 \cdot 3 \\
+1 \cdot 8 \\
+\quad 6.4 \\
+1 \cdot 0 \\
+\quad 3 \cdot 0 \\
+4.6\end{array}$ \\
\hline & & & & Mean & +2.69 \\
\hline
\end{tabular}

\begin{tabular}{|c|c|c|c|c|c|}
\hline $\begin{array}{l}\text { Station ... } \\
\text { Longitude. }\end{array}$ & \multicolumn{2}{|c|}{$\begin{array}{l}\text { Bombay. } \\
72^{\circ} 48^{\prime} \mathrm{E}\end{array}$} & \multicolumn{2}{|c|}{$\begin{array}{l}\text { Batavia. } \\
\text { xo5 } 50^{\prime} \mathrm{E} .\end{array}$} & $\begin{array}{c}\text { Batavia } \\
\text { minus } \\
\text { Bombay. } \\
+34^{\circ} 2^{\prime} .\end{array}$ \\
\hline $\begin{array}{l}\text { First } \\
\text { Set. }\end{array}$ & $\begin{array}{l}\text { Year. } \\
1867 \\
1869 \\
1872 \\
1873 \\
1874 \\
1875 \\
1875 \\
1876\end{array}$ & $\begin{array}{r}\text { Month. } \\
\text { 12.8 } \\
6.9 \\
4.5 \\
5.8 \\
5.4 \\
3.7 \\
9.7 \\
\text { 10.2 }\end{array}$ & $\begin{array}{l}\text { Year. } \\
1868 \\
1869 \\
1872 \\
1873 \\
1874 \\
1875 \\
1875 \\
1876\end{array}$ & $\begin{array}{r}\text { Month. } \\
2 \cdot 1 \\
8 \cdot 5 \\
5 \cdot 6 \\
6 \cdot 8 \\
6 \cdot 7 \\
4^{\circ} \cdot 9 \\
10^{\circ} \cdot 0 \\
9 \cdot 8\end{array}$ & $\begin{array}{l}\text { Month. } \\
+\mathrm{r} \cdot 3 \\
+\mathrm{r} \cdot 6 \\
+\mathrm{r} \cdot \mathrm{I} \\
+\mathrm{r} \cdot 0 \\
+\mathrm{r} \cdot 3 \\
+\mathrm{r} \cdot 2 \\
+\quad 0 \cdot 3 \\
-0 \cdot 4\end{array}$ \\
\hline $\begin{array}{l}\text { Second } \\
\text { Set. }\end{array}$ & $\begin{array}{l}1869 \\
1873 \\
1874 \\
1875 \\
1875 \\
1876 \\
1878\end{array}$ & $\begin{array}{r}8 \cdot 1 \\
6 \cdot 2 \\
5 \cdot 7 \\
4^{\circ} 0 \\
11^{\circ} \cdot 2 \\
4^{\circ} 9 \\
5^{\circ} 9\end{array}$ & $\begin{array}{l}1869 \\
1873 \\
1874 \\
1875 \\
1875 \\
1876 \\
1878\end{array}$ & $\begin{array}{r}\text { 10.0 } \\
7.5 \\
7.5 \\
6.0 \\
9.7 \\
6.1 \\
7.9\end{array}$ & $\begin{array}{l}+1 \cdot 9 \\
+1 \cdot 3 \\
+1 \cdot 8 \\
+\quad 2 \cdot 0 \\
-1 \cdot 5 \\
+1 \cdot 2 \\
+\quad 2.0\end{array}$ \\
\hline & & & & Mean & $+\mathrm{I} \cdot 07$ \\
\hline
\end{tabular}

\begin{tabular}{|c|c|c|c|c|c|}
\hline & \multicolumn{2}{|c|}{ Solar spotted area. } & \multicolumn{2}{|c|}{ Bombay barometer. } & \\
\hline $\begin{array}{l}\text { First } \\
\text { Set. }\end{array}$ & $\begin{array}{l}\text { Year. } \\
\text { 1862 } \\
1863 \\
1863 \\
1864 \\
1865 \\
1866\end{array}$ & $\begin{array}{r}\text { Month. } \\
3.4 \\
\text { I.3 } \\
\text { I I.7 } \\
\text { I } 2 \cdot 7 \\
9.4 \\
6.0\end{array}$ & $\begin{array}{l}\text { Year. } \\
1862 \\
1863 \\
1865 \\
1866 \\
1867 \\
1867\end{array}$ & $\begin{array}{r}\text { Mcnth. } \\
6 \cdot 7 \\
\mathrm{I} 1 \cdot \mathrm{I} \\
\mathrm{I} \cdot 8 \\
\mathrm{I} \cdot \mathrm{I} \\
\mathrm{I} \cdot 5 \\
\mathrm{I} 2 \cdot 8\end{array}$ & $\begin{array}{l}\text { Month. } \\
+\quad 3.3 \\
+9.8 \\
+14.1 \\
+12.4 \\
+16.1 \\
+18.8\end{array}$ \\
\hline & & & & Mean & +124 \\
\hline
\end{tabular}

\begin{tabular}{|c|c|c|c|c|c|}
\hline \multirow[b]{2}{*}{$\begin{array}{l}\text { First } \\
\text { Set. }\end{array}$} & \multicolumn{2}{|c|}{ Solar spotted area. } & \multicolumn{2}{|c|}{ Madras barometer. } & \multirow[b]{2}{*}{$\begin{array}{l}\text { Month. } \\
+6 \cdot 1 \\
+6.2\end{array}$} \\
\hline & $\begin{array}{l}\text { Year. } \\
1849 \\
1850\end{array}$ & $\begin{array}{c}\text { Month. } \\
6.7 \\
\text { II } 2\end{array}$ & $\begin{array}{l}\text { Year. } \\
\text { I } 849 \\
1851\end{array}$ & $\begin{array}{c}\text { Month. } \\
\text { I } 2 \cdot 8 \\
5 \cdot 4\end{array}$ & \\
\hline & & & & Mean & $+6 \cdot I$ \\
\hline
\end{tabular}

It will be seen that in the great majority of cases the baro. metric waves reach the westerly station several months before they arrive at the more easterly one, but that the rate of pro. gression of these waves across the Indian Peninsula appears to be much slower than across the open ocean to the southward.

F. C

\section{THE ROYAL SOCIETY-ADDRESS OF THE PRESIDENT 1}

$D^{R}$. SPOTTISWOODE began by referring to the losses which the Society has sustained by death during the past year :- Prof. Miller, Dr. Sharpey, Mr. Lassell, Prof. Ansted, Lord Belper, Mr. E. W. Cooke, and Sir Benjamin Collins Brodie.

The Society's finances generally are, as the balance-sheet will show, in a healthy condition, and appear to justify the hope that they will suffice for the large claims upon them for printing our publications, The address then proceeds :-

Although we are more concerned, Dr. Spottiswoode said, with the quality than with the quantity of communications made to the Society, it may not be without interest to observe that the number of papers received this year has been in excess of that in any previous year, at all events since 1872 , inclusive. The following is a table of the numbers during the last nine years :-

\begin{tabular}{|c|c|c|c|c|c|c|c|}
\hline 1872 & ... & $\cdots$ & $\cdots$ & $\cdots$ & \multicolumn{3}{|c|}{99 papers received. } \\
\hline 1873 & $\ldots$ & $\cdots$ & $\ldots$ & $\ldots$ & 92 & $"$ & \\
\hline 1874 & $\ldots$ & $\ldots$ & $\ldots$ & $\ldots$ & 98 & ," & \\
\hline 1875 & $\cdots$ & $\ldots$ & $\cdots$ & $\ldots$ & 88 & $"$, & $"$ \\
\hline 1876 & $\cdots$ & $\ldots$ & $\ldots$ & $\ldots$ & I1 3 & ," & ", \\
\hline 1877 & $\cdots$ & $\ldots$ & $\cdots$ & $\cdots$ & 97 & ", & ", \\
\hline 1878 & $\cdots$ & $\cdots$ & $\cdots$ & $\cdots$ & I Io & ", & ", \\
\hline 1879 & $\cdots$ & $\cdots$ & $\cdots$ & $\cdots$ & 118 & ," & ", \\
\hline & ... & $\cdots$ & $\cdots$ & $\ldots$ & 123 & , & ", \\
\hline
\end{tabular}

and we may conclude that these have contained good matter from the fact that of the Philosophical Transactions for the current year Parts i. and ii., already published, contain no less than 900 pages and thirty-three plates.

Dr. Spottiswoode then referred to the satisfactory results of the change of time of meeting of the Society, and went on to speak of the death of Mr. Henry White, who for many years was chief assistant in the compilation of the great Catalogue of Scientific Papers. At an earlier stage of the work, Dr. Spottiswoode went on to say, his loss would have been still more serious ; but in a long course of training he succeeded so well in imparting his own careful and methodical mode of work to those under him, that the Council felt justified in making trial of his son to take his place. With the result of this trial, as shown in continuing the preparation of a new edition of the catalogue of the Society's Library, the Council has reason to be satisfied. Of this new edition, the first portion, 220 pages, containing our large collection of Transactions and Proceedings of Academies and Societies, and other scientific periodicals is in type, and will shortly be printed off. The verification of titles of our scientific books generally is so far advanced as to warrant the expectation that a large iastalment of this portion of the catalogue will soon be in the printer's hands; after which we anticipate no.further delay.

In rexard to the Library, a cuestion has arisen as to how far purely literary works, which occupy much space, should be retained. Among them there are doubtless some which add neither to the utility nor to the scientific importance of our Library, but there are also some early printed books, bibliographical treasures, which are worthy of a place in any collection. It is proposed to have these carefully put in order, and to place them in a case by themselves. Among these, there may be mentioned :-

Caxton's Chaucer, 1480 .

Pynson's Chaucer, 1492.

Speght's Folio Chaucer, 1598 .

Ciceronis Officia et paradoxa, Fust, 1466, vellum.

The generall historie of Virginia, Lond. I632.

Bonifacius. Sextus decretalium liber. Ven. 1566.7

Plautus, 1482. Seneca, I490.

Ovid, 1485. Statius, 1490.

Plutarch, I485. Herodotus, 1494.

Homer, 1488 .

For bringing into prominence these as well as other features of our miscellaneous, i.e. non-scientific, books, we are greatly in. debted to the care and knowledge brought to bear on the subject by $\mathrm{Mr}$. Tomlinson, and by our treasurer.

Although it is doubtless undesirable to propose, without sufficient cause, alterations in our statutes, or even in our practice, it is still often worth while from time to time to discuss questions involving such alterations in order that we may be prepared for a

${ }^{2}$ Address of William Spottiswoode, D.C.L., LL.D., the President, delivered at the Anniversary Meeting of the Royal Society on 'Tuesday, November 30,1880 
deliberate judgment whenever occasion may arise. Among such subjects there is one upon which I have often heard opinion expressed, and upon which opinion has always weighed in the same direction: I allude to the period of office of those elected to serve on the Council of the Society. By the terms of our charter ten of the ordinary members retire every year; and as it is our custom to remove six according to seniority and four in respect of least attendance, it rarely happens, although the contrary is possible, that any Fellow, except those holding the posts of President, Treasurer, or Secretary, should remain in office more than two years. Experience, however, appears to show, that for a member serving on the Council for the first time, there is so much to learn, so many heads of business which do not in general come before the Fellow's at large, that his first year is occupied quite as much in ascertaining his duties as in actively performing them. This objection is in some degree met by selecting for the ten incoming members five who have served before, and five who have not so served; but, nevertheless, there is usually an interval of several years between two periods of office, and as a matter of fact we often lose a member of Council at the moment when his advice is becoming most valuable to our body.

I am aware of the great convenience attaching to our present impersonal mode of selecting the members to retire in each year, and am not at present prepared to suggest any specific alteration. But, the great confidence which the Society has, especially of late years, placed in its more permanent officers, and the power which naturally accrues to them from the comparatively short tenure of office by the other Members of Council, appear to me to be points of which the Society should not lose sight. On the part of the officers I think it right to state that we are very sensible both of the honour which is thus done to us and of the responsibility which is thereby entailed, and that we hope never to discredit the one nor to abuse the other. And having said so much, we are quite willing to leave the matter in the hands of the Society to be taken up whenever they see reason so to do.

It will be in the recollection of the Fellows that the position of the Royal Society in respect of the Government Fund of 4000 . per annum is different from that in relation to the Government Grant of roool. per annum. In the latter case the sum is placed unreservedly in the bands of the Society for promoting scientific investigation, subject only to an annual report to the Treasury of the disposal of it; and, in administering it, the Society has in no case applied it to the personal remuneration of the applicant. In the former case the Society has been requested to advise the Science and Art Department as to the distribution of the grant, not only for the direct expenses of investigations, but also for personal remuneration for the time expended on them, whenever the circumstances and wishes of the applicant appeared to render this desirable. 'The responsibility of this advice lies with a Committee similar to that of the Government Grant, but with the addition of the presidents of certain learned bodies and societies, nominated for that purpose by the Government.

The recommendations made by the Committee each year are annually published in the Proceedings, so that the public will have had full information as to the distribution of the grant; while the Fellows have the opportunity of seeing the nature of applications made, and the extent to which it has been found practicable to meet them, as recorded in the minutes of the Council of the Society.

One of the points which is perhaps beset with the greatest difficulty is that of the so-called "personal" grants. On the one hand it has been argued that it is desirable to enable the man of small means to devote to research a part of his time which he could not otherwise afford to give ; but, on the other, the question has been raised whether it be wise, even in the interests of science, to encourage any one not yet of independent income to interrupt the main business of his life. It is too often assumed that a profession or a business may be worked at half-speed, or may be laid down and taken up again, whenever we like. But this is not so, and a profession temporarily or even partially laid aside, may prove irrecoverable; and the temptation to diverge from the dull and laborious path of business may prove to have been a snare. Without proposing to exclude from possible aid in some shape or other those cases where personal assistance may be safely offered, it has been suggested that many such cases may be practically met by grants for the employment of an assistant, instear of grants to the applicant himself.

There is another fundamental difference between the position of the Government Grant of $1000 l$. per annum and the Govern. ment Fund of $4000 \mathrm{l}$. per annum, which appears to me to be of material importance in the interests of science. The former is an absolute grant from the Treasury made to the Society for scientific purposes. It may be used wholly, or in part, during the year in which it is made, and the balance, if any, may be carried over by the Society to the next or even to succeeding years. The latter is a vote to the Science and Art Department, on the disposal of which the Society is consulted. Like all other similar votes, any unused balance reverts to the Treasury, and is to that extent lost to the purpose for which it was intended. I cannot help thinking that, if any such balances could be reserved and kept in hand, provision might be made for some larger purposes than those to which the fund has hitherto been devoted. And, even if having this end in view, the Committee should not see its way to recommend some of the smaller applications, it may be fairly questioned whether the smaller grants might not find a more appropriate place among those of the Donation Fund of this Society, or of the British Association, or among some of those separate funds which, through the liberality of individuals, are now growing up among the special societies.

I am glad to record the fact that, upon the recommendation of men of science, Her Majesty has been pleased to grant pensions on the Civil List to the widows of two of our late Fellows, viz., to Mrs. John Allan Broun and to Mrs. Clifford.

Last year two volumes containing a collection of the late Prof. Clifford's general lectures and essays were bronght out. It is hoped that during the present winter a collection of his mathematical papers will be published. The contributions to science by the late Prof. Rankin have recently been placed in the hands of the public. While very sensible of the obligations inder which the scientific world is placed by these posthumous publications, I cannot refrain from alluding to our obligations, even greater if possible, to those who during their lifetime are willing to re-issue their own scientific memoirs, and to give us the:eby not only the convenience of ready access, but also the advantage of their own subsequent reflections on the subjects of which they have treated. And at this particular moment I desire to mention more particularly the mathematical and physical papers of our Senior Secretary, Prof. G. G. Stokes; and, while expressing our gratitude for the volume which has already appeared, I would express also our sincere hope that another instalment from the same source may shortly follow.

Among the subjects which at one period of the late session of Parliament engaged the attention of the Government was that of the law relating to vaccination; and a Bill was introduced intended to remove some of the practical difficulties in carrying out the existing law. While fully admitting the difficulties in question, the remedy proposed appeared to trench so closely upon the application at least of a scientific principle, and at the same time to be so important in its practical aspect, that I ventured (although the Council was not sitting) to consult the Presidents of the Colleges of Physicians and of Surgeons, and that of the Medical Council, about addressing the Government on the subject, This resulted in a joint deputation to the President of the Local Government Board, in which I took part as President of the Royal Society. I reported this matter to the Council at their first meeting after the recess, and received their approbation. The Bill in question was withdrawn.

The Royal Commission on Accidents in Coal Mines, the appointment of which I mentioned in my address of last year, has been nccupied principally in bringing together a hody of valuable evidence on the causes and prevention of accidents in mines generally. The Commission has also visited a number of mines in which serious accidents by explosion have taken place, or in which certain phenomena connected with the occurrence of fire-damp were to be studied. They have also instituted a series of experiments on the behaviour of various safety lamps in mixtures of natural fire-damp and air. These experiments they are about to renew during the winter. They also contemplate carrying out experiments in blasting rock and coal by methods which will check the production of flame, and which are thereby calculated to obviate the danger of igniting fire-damp.

The report of the voyage of H.M.S. Challenger, to which the scientific world has been looking forward with so much interest, is now so far advanced that one volume of the "Zoological Memoirs" will appear immediately. In addition to this a second volume may be expected within a year. The first volume of the whole, work, "containing a short narrative of the 1 voyage, with all necessary hydrographical details, an account of the appliances and methods of observation, a running 
outline of the results of the different observations; and a chapter epitomising the general results of the voyage," together with the second volume containing the meteorological, magnetic, and hydrographic observations, will probably be published within the same period. "The general report on the zoology of the expedition will consist of about fifty distinct memoirs, which will occupy from ten to twelve volumes." It has been arranged "to

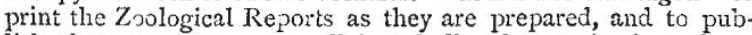
lish them as soon as a sufficient bulk of memoirs is ready to form a volume. Cofiez of each memoir may also be had separately, in order that working naturalists may have thein in their hands at the earliest possible date." Two more volumes on the geology and petrology, and one on the general chemical and physical results, will probably complete the series. Into the detrils of the zoological results I am not competent to enter; but the greatest interest attaches to the fact that notwithstanding the pre-sure and absence of light, there is no depth-limit to animal life. A t the Council of the Meteorological Office is nominated by the Council of the Royal Society, and as the Annual Report of the Office is submitted to the Royal Society, I think it right to mention a few points connected with the work of that department during the past year.

I. A method of recording the duration of bright sunshine by the charring of an object placed in the focus of a glass sphere, freely exposed to the rays of the sun, was devised by Mr. J. F. Campbell of Islay in 1856 ; and instruments, being modified forms of that originally proposed, have been employed for some time at Greenwich, at Kew, and at a few private observatories. Certain difficulties in adjusting the paper about to be charred to the path of the burning spot, which had hitherto prevented the adoption of Mr. Campbell's invention as a part of the ordinary equipment of a meteorological observing station, have been at last successfully overcome by an arrangement designed by Prof. Stokes; and thirty stations in the British Isles have now been supplied with instruments of the pattern proposed by him. We may thus hope to obtain in future a sufficient record of a meterological element, which is of primary inmportance in its relations to agricul.ure, and to the public health, but which has hitherto been very imperfectly registered.

2. The climatology of the Arctic regions, in addition to its importance as a part of the general physics of the globe, possesses a special interest in connection with geographical exploration. As a contribution to our knowledge of this subject, the Meteorological Office has entrusted to Mr. R. Strachan the task of bringing together, and discussing on an uniform plan, the results of the observations taken at intervals during the last sixty years, in the region extending from the meridian of $45^{\circ} \mathrm{W}$. to that of $120^{\circ} \mathrm{W}$., and from the parallel of $60^{\circ}$ to that of $80^{\circ}$, either at land stations or at the winter quarters of British and American expeditions. A considerable portion of this discussion has been already published; the remainder may be expected in the course of next year.

3. Another publication of the Meteorological Office may be mentioned as serving to mark the advance in meteorological theory, which has been achieved during the last fifteen years. The old "Barometer Manual and Weather Guide" of the Board of Trade has been replaced, so far as it relates to the weather of the British Isles, by a work entitled "Aids to the Study and Forecast of Weather," prepared under the direction of the Meteorological Office by the Rev. W. Clement Ley. Though some of the views put forward in the later work may, nerhaps, be regarded as not sufficiently established by observation, yet a comparison of the two works cannot fail to leave upon the reader's mind the impression that in the interval between their respective dates of publication, some real progress has been made in meteorology. Perhaps this is most conspicuous in the enlarged ideas that are now entertained concerning the conditions upon which the changes of weather depend. Local weather was first discovered to be contingent upon travelling areas of disturbance, each of which averaged mairy hundreds of miles in diameter, while, at the present time, the relation of these areas to one another, as parts of a single terrestrial system, has become a prominent topic of inquiry. If meteorology has thus been, to a certain extent, rescued from the ever-accumulating choas of numerical tabulations, which threatened to engulf the whole science, the im. provement is mainly due to the development in recent times of the synoptic study of weather over large regions of the earth's surface, to which so great an impetus has been given by the extended facilities of telegraphic communication.
4. Balloon ascents, with a view to military purposes, are now systematically carried on under the direction of the War Office ; and the endeavour has been made to take advantage of these ascents for observations of the thickness of the aërial current which causes our winds, and of the peculiarities of the currents above it in the upper strata of the atmosphere. The military authorities have offered their.co-operation in the most cordial manner; but the attention of an aeronaut is often so much engrossed by the operations necessary for working his balloon, that he has but little leisure for taking systematic records. Nevertheless, observations of considerable interest have already been obtained, relating especially to the velocity and direction of the upper air currents ; and there can be no doubt that a continuance of such observations affords the best prospect at present open to us of adding to the very scanty knowledge which we possess of the movements of the atmosphere, even at a moderate height above the earth's surface.

Among the various duties which the President of the Royal Society is called upon to fulfil, there are those of a Trustee of the British Museum; and, as an operation 'of great importance to science, namely the removal of the natural history collections to the new building at South Kensington, is now going on, the Fellows may be interested to hear what progress has been made in the work.

The plans for the new building were approved as long ago as April, 1868: but the works were not commenced until the early part of 1873 . Their progress was retarded by difficulties in the supply of the terra cotta with which the building is faced within and without, and in which the mouldings of arches and other ornamental features are executed.

The building was finally handed over to the Trustees in the month of June of the present year. It contains cases for three only of the departments for which it is intended, namely, Mineralogy, Geology, and Botany; the necessary funds for the Zoological Department not having yet been voted. As the latter collections are equal in bulk to the other three collectively, it follow's that only half the new building can at present be actually occupied. The removal of the collections for which cases had been provided, commenced in the last week of July, and was virtually completed by the end of September.

Geology, which was very inadequately displayed in the old building, is now more commodiously accommodated. It now occupies a gallery 280 feet in length by 52 in breadth, forming the ground floor of the east wing of the new museum, together with eight other galleries covering an area of $200 \times 170$ feet at the back, and admirably adapted for the exhibition of the specimens. One of these galleries will be devoted to the illustration of stratification.

The principal part of the Minerals has been moved and replaced in the cases in which they were arranged in the old building. The collection now occupies the first floor of the east wing of the new museum, and the space devoted to it is $280 \times 50$ feet in area. It is already arranged for exhibition.

The Botanical collections are placed in the gallery over the minerals, where the space for exhibition and the conveniences for study are much greater than in their old quarters.

The constraction of the cases for the Zoological specimens, and the ultimate removal of these collections, must depend upon the amount of the Parliamentary vote for the purpose; but under the most favourable conditions it can hardly be hoped that this department can be open to the public or to students for two years from the present time.

The "Index Museum," designed by Professor Owen, will form a prominent feature in the new museum. The object of it, in his words, is "to show the type characters of the principal groups of organised beings ;" and "to convey to the great majority of visitors, who are not naturalists, as much informa. tion and general notions of its aim as the hall they will first enter and survey could be made to afford."

One of the principal difficulties attending the transfer of the Natural History Departments to a separate building consists in the provision of books for the use of the keepers and their staff, as well as for students who may visit the museum. Hitherto the separate collections of books, known as departmental libraries, supplemented as occasion might require from the main library of the museum, have sufficed for all purposes. But now, when the departmental libraries have to stand by themselves, it is impracticable to carry on even the current work of arrangement without additional resources. For an adequate supply of the necessary works a very large outlay would be required, sup. 
posing that the works were in the market. But many of them are out of print and have become scarce; and a large grant of public money would perhaps raise the market price almost in proportion to its magnitude. This being so, it has been thought best, on the whole, by the Government to make an annual grant to be expended from time to time as favourable opportunities for purchase may offer. If it should prove possible, and on other grounds desirable, to allow the Banks' Library to follow the collections with which it has always been practically con. nected, the wants of the Natural History Departments would (so far as books up to the date of its bequeathment are concerned) be in a great measure supplied.

Another of the duties which falls officially on your President is to take part in the organisation of technical education as promoted by the City and Guilds of London Institute, which is now incorporated under the Companies Acts, 1862-80, as a registered association, and of which the Presidents of the Royal Society, the Chemical Society, the Institute of Civil Engineers, and the Chairman of the Council of the Society of Arts, are members. In the Memorandum and Articles of Association of the Institute, its objects are fully set forth. They may be summarised under the following heads :-

I. The establishment of a central technical institution for instruction in the application of science and art to productive industry.

2. The establishment of trade and technical schools in London and in the country.

3. The development of technical education by means of examinations held at the Central Institution, or at other places.

4. To assist by means of grants existing institutions in which technical education is being promoted.

5. To accept gifts, bequests, and endowments for the purposes of the Institute.

The Institute is supported by subscriptions from sixteen of the City Companies, of which the largest contributors are the Mercers, Drapers, Fishmongers, Goldsmiths, and Clothworkers.

The Institute has been in active operation not much more than a year, and during the last six months the work of the Institute has developed considerably in each of its several departments. These may be considered under the following heads :-

I. Technical Instruction.

2. Examinations in Technology.

3. Asssistance to other Institution".

I. Since November last courses of lectures and laboratory instruction have been given in the temporary class-rooms of the Institute, at the Cowper Street Schools, under the direction of Prof. Armstrong, F.R.S., and of Prof. Ayrton. The subjects of instruction have included Inorganic and Organic Chemistry, with special reference to their industrial applications ; Fuel, Electrodepositions of Metals, and Photographic Chemistry; General Physics, Steam, Electrical Engineering, Electrical Instrument Making, Electric Lighting, Weighing Appliances, and Motor Machinery.

During the term ending July last the number of tickets issued to students, most of whom belonged to the artisan class, exceeded three hundred. A considerable accession of students is expected as soon as the building in Tabernacle Row, the plans of which are already settled, shall be erected. This building, which is estimated to cost $\{20,000)$, will provide accommodation for schools of Technical Physics, Technical Chemistry and Applied Mechanics. Many of the day students at these classes are pupils of the Cowper Street Schools, and it is expected that, by adapting the course of technical instruction to be given in the College to the wants of these boys, a very complete technical school for the children of artisans will have been established.

The evening lectures and laboratory instruction, which are more advanced and more special, are attended very largely by external students, for whom the present temporary accommodation is already too limited.

At Kensington, schools have been established in which practical instruction is given in various art subjects, such as Painting and Drawing, Modelling, Designing, and Wood Engraving. These schools are attended by both sexes, and are under the immediate direction of Mr. Sparkes. The numbers in attendance last term were as follows :-

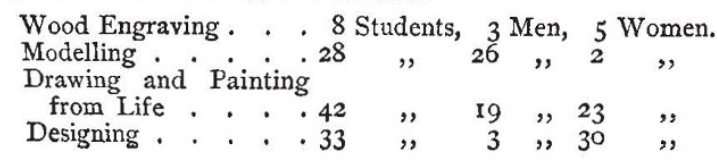

The Central Institution for instruction in the application of the higher branches of science to industrial pursuits is about to be erected on a plot of ground in Exhibition Road, granted by the Commissioners of $185 \mathrm{r}$. The construction of this building, which, when completed, will cost $50,000 l$, , has been entrusted to Mr. Alfred Waterhouse, who is now engaged in the preparation of plans.

2. In the year 1879 , the examinations in Technology, which had been initiated by the Society of Arts, were transferred to this Institute. Various charges where introduced into the regulations. New subjects were added, and in order to stimulate the teaching of Technology throughout the country, the principle of payment to teachers on the results of the examinations was adopted. The encouragement thus afforded to teachers gave a great impetus to the formation of classes throughout the country in technological subjects. Last year the number of candidates for examination was 202, while"at the recent examination, held in May, 816 candidates presented themselves, of whom 515 satisfied the Examiners. During the last few months the number of classes throughout the country, in which technical instruction is being given, has considerably increased, and, judging from the returns already received, there is reason to believe that the number of candidates, who will present themselves for examination next May will be much greater than in either of the preceding years. The new programme, which is just issued, contains a syllabus of each subject of examination, and every effort has been made, short of testing the candidates' practical skill, to make the examinations as efficient as possible. To obtain the Institute's full certificate, each candidate is required to give evidence of having obtained some preliminary scientific knowledge.

3. In order to take advantage of efforts that are already being made to advance technical education, the Institute has given sums of money for specific objects to several institutions in which technical instruction is provided. The schools, colleges, and other bodies which have received grants from this Institute, are University College and King's College, London, the School of Art, Wood Carving, and Mining Association of Devon and Cornwall, the Nottingham Trade and Science Schools, the Artisans' Institute, the Birkbeck Institute, the Lancashire and Cheshire Union, and the Horological Institute.

The Artisans' Institute gives practical instruction in several of the humbler crafts in which artisans are engaged, such as carpentry, zinc work, and plumbers' work; and corresponds, therefore, to some slight extent with the apprenticeship schools of the Continent, from which, however, it differs in many im: portant particulars. A similar experiment is being tried at the Horological Institute, where, at the expense of the Guilds, classes have been organised, in which apprentices receive practical instruction in the various branches of the watch-making trade.

It is found that the demand for technical instruction in London and throughout the provinces is very great, and the efforts that have been so far made by the City and Guilds of London Institute have been received with considerable satisfaction by artisans and others engaged in industrial pursuits, and promise, when further extended, to be of the utmost service in the development of technical education in this country. Turning now more particularly to the progress and the applications of science, I venture to make mention of a few topics which have come under my own observation.

(To be continued.)

\section{OUR ASTRONOMICAL COLUMN}

LUNAR ECLIPSES, 1880-84. - The total eclipse of the moon is only partly visible in this country, the middle occurring at $3 \mathrm{~h}$. $39 \mathrm{~m}$. Greenwich time, and the moon not rising until seven minutes later; the end of the total phase takes place at $4 \mathrm{~h}$. $24 \mathrm{~m}$., and the last contact with the earth's shadow at $5 \mathrm{~h} .33 \mathrm{~m}$. In Australia the whole eclipse may be witnessed to advantage. On December 5, 188r, there will occur an almost total eclipse (magnitude $0^{\circ} 97$ ), again only partly visible here; the first contact with the shadow at $3 \mathrm{~h} .28 \mathrm{~m}$., and the moon rising at $3 \mathrm{~h}$. $50 \mathrm{~m}$. ; greatest phase at $5 \mathrm{~h} .8 \mathrm{~m}$. In 1882 there will be no lunar eclipse. On October 16,1883 , a partial eclipse is barely visible here ; first contact with the shadow at 5 h. 59m. a.m., the moon setting at $6 \mathrm{~h} .25 \mathrm{~m}$. The next favourably-circumstanced lunar eclipse, as regards observation in this country, will take place on the evening of October 4,1884 ; first contact with shadow at $8 \mathrm{~h}$. $15 \mathrm{~m}$, , beginning of total phase at $9 \mathrm{~h}$. $16 \mathrm{~m}$., middle of the eclipse 